\title{
タイ王国船員教育訓練センター拡張近代化 プロジェクトの技術協力概要*
}

林 和 宣**

\section{1.はじめに}

近年，海外の発展途上国から，我か国に対して船 員教育に関する援助依頼がとみに増大してきている。 筆者が携わっているJICA（国際協力事業団）のプ ロジェクト「タイ王国船員教育訓練センター(Merchant Marine Training Centre) 拡張近代化プロ ジェクト」も，その中の一つである．以下に昨年 3 月から開始された本プロジェクトの概要を紹介する とともに，多少の解説を加えてみることとする.

\section{2. 現代夕イ事情}

まずタイ国というと誰しも思い出すのが，南の暑 い国で日本とは南蛮貿易の頃から交流のあった敬虔 な仏教 (小乗仏教) 国だということ之，象や藏など に象徵される野性の動・植物の豊かな国であると之 もに東南アジアに於ける歴史的な文化財も多く観光 のメッカだということである. またつい最近では, 我が国への米の輸出問題で取り沙汰された国でもあ る. 一般的には以上のような印象のあるタイ国であ るが，実際の夕イ国は東南アジアに於て，隣国のマ レーシアとともに経済発展を競い合うトップクラス の発展途上国である．その背景としては，外資の導 入が比較的自由で，我が国を始め多くの外資が導入 されており，これらの外資がこの国の安価な労働力 とあいまって, 現在の商・工業の発展に大いに寄与 しているようである. 因みにバンコク及び近郊地域 での1994年10月（'95年会計年度始め）現在におけ る最低賃金は B 135／日（135バーツ／日 : 約540円） で，正式な労働組合も無いような状態である.

*原稿受付 平成 6 年 12 月 7 日

**正会員 運輸省航海訓練所教授

（横浜市中区仲通 5 丁目57番地）
タイ国に於ける近代化についてはバンコクを中心 として近年とみにその発展が著しく，最近の急速な 経済発展によるGNPの上昇により，昨年度で我が 国のODA無償供与対象国から離れた。その顕著な 例が, 現在のバンコク市内の建設ラッシュと交通渋 帯である.日く，「バンコクは世界の自動車の駐車 場である」。もともと都市計画に於ける道路事情が 自動車の急激な普及に適していなかったことや，鉄 道の普及の遅れ等が重なり合った結果と思われるが, 都市部におけるインフラ整備が実施される以前に経 済発展が先行した形の現れであろうと思われる．経 済の急速な発展とともに，その半面で生じてきたの が貧富の差である．都市部之地方の差は大きく，一 例として前記の最低賃金にもその差は歴然としてお り，前者のB135に対して後者のB 110である.

経済発展とは切っても切り放せない要素として政 治が挙げられるが，この国の政治・外交を過去に遡 り振り返ってみると次のとおりである. まずタイの 主要民族であるシャム族が独立国家として歴史に登 場したのが13世紀で，アンコール朝の支配下にあっ たスコータイを占拠して，その地を中心とする独立 王国を建設した. スコータイ朝は三代目のラームカ ムヘン王のとき，その勢力圏を急速に拡大し，中国 から製陶技術を導入, タイ文字の創作，スリ・ラン カから南方上座部仏教 (小乗仏教) の伝播等を果た して, タイ民族文化発展の基礎を築いた.

1351年, チャオプラヤー川下流に興ったアユタヤ 朝は，やがてスコータイ王国を併合して統一国家を 形成した.アアユタヤ朝は軍事的手段による勢力圈の 拡大, 行政機構の整備, 度重なるビルマとの戦争 （1569年には，首都アユタヤがビルマ軍により奪取 されたが後に，これを撃退した。），諸外国との交 易(日本からも御朱印船が多数アユタヤを訪れた.) などを通じ，一大商業・政治都市へと発展して文芸 
は黄金時代を迎えた。

1767年, ビルマ軍によってアユタヤは徹底的に破 壊され, アユタヤ王朝は滅亡した. その後のターク シン王がビルマ軍を破り, アユタヤを解放, 独立を 回復してチャオプラヤ川の河口に近いトンブリに新 しい都を建設したが，15年後に滅亡した。

トンブリ朝に変わってチャクリが王都対岸のバン コクに移して現在のラタナコーシン朝を開いた.

ラーマ一世は, 相次ぐ戦乱によって荒廃した秩序の 回復者として知られ, 新王朝の経済的基礎を固める ため, 対中国貿易の推進に意を用いた. ラーマ四世 モンクット王は，ヨーロッパ列強に対して門戸を解 放し，イギリス・アメリカ及びフランスと相次いで 修好通商条約を締結した。

ラーマ五世チュラロンコン王は, 巧みな外交政策 によりイギリス・フランスによる植民地化の危機を 回避しつつ, 国内的には地方行政制度の整備, 国民 教育の発展, 近代法典の整備, 権利 - 財政制度の確 立, 近代的軍隊の創設など, いわゆる「チャクリ改 革」によって, 絶対君主的支配体制を成立させた.

ラーマ七世プラチャテイボック王の時に, 立憲改 革（1932年）が発生, 専制君主側から立憲君主制に 移行した。

立憲革命後は, 1957年のサリット・クーデターに よる陸軍の主導的地位の確立, 73年の流血事件を契 機に, 夕ノム軍事政権が崩壊, 文民内閣の成立, 軍 部によるクーデター，軍部を背景としたターニン内 閣の成立, 更にはクリアンサック内閣, 8 年以上に 渡るプレム内閣が続き, 88年選挙によるチャチャイ 連立内閣が成立した。 就任以来, 順調な経済発展, 好景気, 活発な内外需要, 石油価格の安定など内外 の要因もあいまって, 安定と高い支持率を誇った チャチャイ内閣も，89年頃から次第にその屋台骨が 摇らぎ始め, 91 年 2 月のクーデターによりアナン・ パンヤラチョンが政権を握った. その後, 92年のクー デターを経て現在のチュアン・リークパイ首相によ る連立内閣に至っている．同連立内閣は，民主化を 進めるうえで, 議会制民主主義の確立を目指して憲 法改正や国軍の再編に取り組んでおり, 政治は安定 の方向に向かいつつあるとの見方が一般的である.

一方外交に話題を転じると，現在夕イ国は141ヶ 国と外交関係を有し，21の国際機関地域事務所が国 内にある. その外交の基本路線は，

1. カンボディア問題を中心とするASEAN結束の
強化 2. 主要援助国である日米欧などの西側先進 諸国との関係強化 3. 中国との良好な関係の維持

4. ラオスなど近隣諸国との関係改善 5 . 共産 圏諸国との経済外交の強化 等にあると言われてい る.

\section{3. 技術協力要請の背颤}

前述のような政治・経済・外交の歴史的背景を 持ったタイ国が近代化を進める中で，ともすればこ れまで夕イ湾内の近隣諸国との交易手段に重点を置 き, 自国産品の輸出や外国からの物品の輸入は, い きおい外国海運に頼っていたのも自然と言わざるを 得ない. しかし，ここに来てにわかに活況を呈して きたタイ経済が，その輸出・輸入を自国海運で行お うとの考えに至るのも又, 経済活動の自然の流れ之 言えよう。そのことは，この国の「国家経済・社会 発展計画」の海運に関する第 6 次計画 $(1987 \sim 1991)$ 及び第 7 次計画 $(1992 \sim 1996)$ に如実に示されてい る. それらの内容の主なものは次のとおりである.

第 6 次計画の骨子

1. 夕イ船籍船の運航効率向上 2 . 沿岸及び外航 の港湾施設の拡充並びに私企業による岸壁整備の推 進 3. 河川・運河・港湾の浚渫による改善 4 . 首都圏の水上交通量の増大 5 . 貨物のコンテナー 化の推進及び国内集荷 - 発送能力の増強 6 . 貨物 のコンテナー化等による異種モード（海上輸送, 列 車輸送, 自動車輸送及び航空輸送）間の連携強化

第 7 次計画の骨子

1. 夕イ海運システムの発展と推進 2 . 外航港湾 の容量増大 3. 政策立案, 協力及び運営の改善 4. 外航港湾の最大限の活用 5 . 私企業の観光 サービス用ボート/フェリーの建造・運航の推進 6. 河川, 運河及び沿岸の水上交通の更なる推進 港湾局情報によると，これらのモットーのもとに 西暦2001年には，外航船・約200隻（必要航海士約 870 名, 機関士約 860 名) 及び内航船・約 110 隻（必 要航海士約310名, 機関士約310名）の商船隊を保有 することを目指している.ここで更に考虑すべきこ とは, 各船舶乗組員数の算定根拠としてキーになる のは, 夕イ船籍の船は乗組員の $75 \%$ がタイ人でなけ ればならないことである，従って，職員のみならず 部員についてもタイ船員を急速に養成しなければな らないということである. 


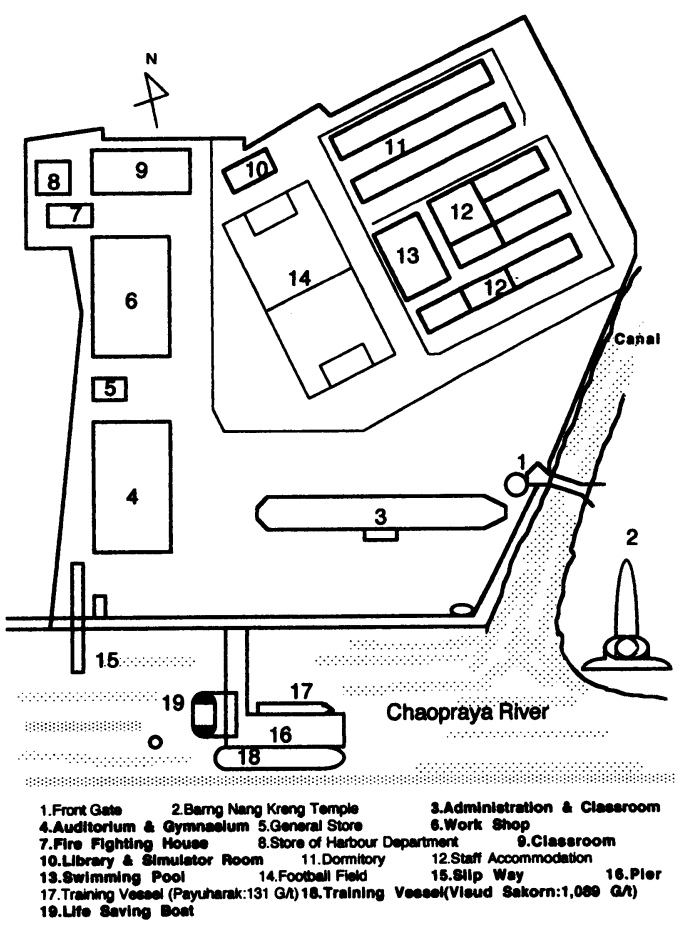

〈Fig. 1〉 Campus and Building Plan

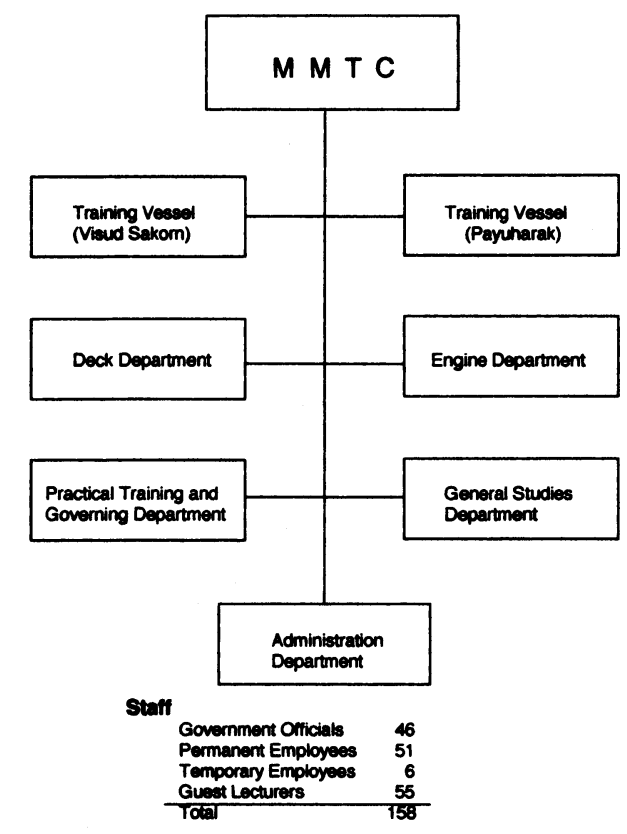

〈Fig. 2〉 Organization Chart of Merchant Marine Training Centre (MMTC)

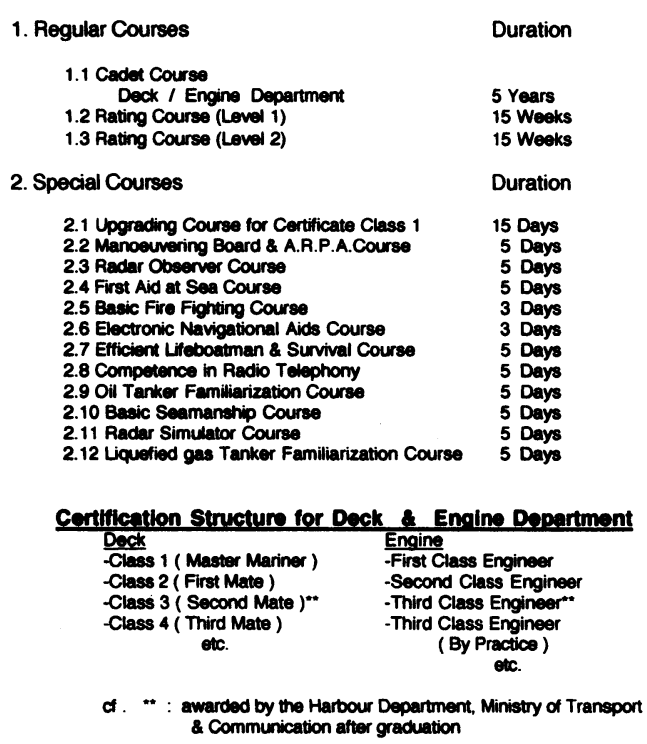

〈Fig. 3 〉 Training Courses

これらの事情を背景として，1972年，自国船員養 成を目指して，運輸通信省港湾局内にタイ王国船員 教育訓練センター（Merchant Marine Training Centre）が設立された，設立当初はタイ・マリタ イム・ナヴィゲーション社の援助のもと 3 年制の比 較的短期養成教育制度であったが，1987年に港湾局 の敷地を離れ,バンコク郊外(南に約 $25 \mathrm{~km}$ ) のサムッ トプラカン市のチュオプラヤ河畔（バンコク港への 入港船から見て右岸に有り，ここから河口までは約 $10 \mathrm{~km}$ ほどある））に校舎を新築して移転した際，力 リキュラムの見直しや，施設の拡充を行い 5 年制の 教育制度とした．またこの時にデンマーク政府の借 款で, 練習船一隻を建造したり, 教育機材の設置を 行った. 以来, この地に於て自国船員養成の努力が 続けられてきた。 (Campus \& Building Plan $\langle$ Fig. 1〉, Organization Chart of MMTC $\langle$ Fig. 2〉, Training Courses 〈Fig. 3〉参照) しかし同時に, この間の世界の海運界における船員 の能力基準の統一化に関する趨勢から，国際航海を 行う商船の乗組員に関する資格等の必要最低限の基 準を定める国際条約（いわゆる, STCW 条約 : International Convention on Standards of Training, Certification and Watchkeeping for Seafarers, 1978） が発効し, 適宜その改正が行わ れてきたことから，タイ国としても早急にその対策 
を実施する必要に迫られ, その援助を, 海運に於て 従来から繫がりのあるデンマークと我が国に要請し た. 我が国に対して最初に技術援助要請があったの は1987年のことであり, 翌年, 第一回目の調查団が 派遣された。 以後1989年及び1992年に，それぞれ調 查団が派遣された後, 1993年 3 月に派遣された「夕 イ王国船員教育訓練センター拡張近代化プロジェク 卜実施協議調查団」（運輸省船員部主幹）によって 技術協力に関する $\mathrm{R} / \mathrm{D} か ゙$ 署名・交換された.これ により，本プロジェクトが実施される運びとなった。 以上からも判るとおり我々の援助の形態は, いうと ころの「プロ技（プロジェクト方式技術協力）」で あり，1. 専門の派遣 2. 研修員受入れ 3. 機 材供与 の三つの要素が, その技術協力の基本と なっている.

ここでプロ技の一般的な実施に至る経緯を述べて みると，おおよそ次のようになる. 先ずプロジェク 卜方式の技術協力は, 日本政府之開発途上国政府之 の共同事業として実施されるので, 両者の責任分担 や附帯条件などについては外務省が取り決めを行う 二国間協定，ないしは実施機関（日本側はJICA） により署名・交換する討議議事録（R/D : Record of Discussions）において明示される. 通常, 実施機関は 5 年程度でまず実施され，その後，技術 の効果的な移転のために更なる援助が必要之認めら れると, phaseをphase-2 として延長されること がある. またプロジェクトの進捗状況に応じて，そ の円滑な推進を図るべく実施される各種調查団の派 遣は，以下のとおりの作業が一連の流れになってい る. 1. 事前調査 2. 実施協議 3 . 実施設計 4. 計画打ち合わせ 5 . 巡回指導 6 . 機材維持 管理 7. 終了時評価 8 . 事後調查 $9 . \quad$ アフ ターケア 10. その他

これによると, 本プロジェクトはプロジェクトの 発掘等を含めた三度の事前調查に基づき，実施協議 及び実施設計により $\mathrm{R} / \mathrm{D}$ 署名・実施に踏み切り, 実施初年度の大詰め (平成 6 年 3 月) で計画打ち合 わせ作業が実施されて現在に至っている.

\section{4. 技術協力の内容}

本プロジェクト技術協力の目標は, タイ国船員教 育訓練センターの設備並びに教育制度の拡張と近代 化を推進することにより，センター卒業生に自国商
船はもとより世界の商船に, IMOのSTCW 条約に 規定された船舶職員あるいは部員として雇用される べき資格を持たせることにある，この目標を達成さ せるために，前述の「プロ技」の三本柱で対応して いる．先ず第一に，専門家の派遣については，チー ムリーダー（1 名: 航海科・長期派遣専門家を兼 任）,JICA調整員（1名）及び機関科・長期専門 家 (1 名) 並びに適宜の短期派遣専門家（目下の之 ころ, 主としてメーカー技術者による供与機材の据 付・取り扱い説明を業務目的亡している．）が配置 されている．第二に，カウンターパートの我が国に 於ける研修については, プロジェクト期間中（平成 5 年 3 月 3 日〜平成 10 年 3 月 2 日）に，供与機材の 導入等を鑑みたうえで, 毎年 3 名のカウンターパー 卜を研修に送り出す計画であり，既に第二陣（平成 5 年度 3 名, 平成 6 年度 3 名）までが研修を経験し ている．第三の供与機材に関しても， R/Dの取り 決めの範囲内において，暫定的ではあるが技術協力 期間中 5 年間の導入機材リストをカウンターパート との協議で作成し, 初年度（平成 5 年度）分の導入 が終わり，目下，第二年度分供与機材入札及び第三 年度分供与機材の仕様書提出の直前となっている.

専門家の活動状況としては，学内の施設及び教育 ・訓練制度の現状確認と将来の展望を見定めたうえ で，長期的な施策を立案して協議するとともに，目 前の懸案に対処すべくカウンターパートとの意思の 疎通を図っている．具体的には，毎月初頭に月例会 議（航海・機関各科及び総務関係カウンターパート 全員が出席），続いて各科毎に毎週月曜日の午前中 に分科会を開催して，プロジェクト業務の進捗状况 の確認並びに促進を行っている. またプロジェクト 推進上問題が生じたときに，適宜両者が検討を行う よう心がけている.

\section{5. 技術協力上の問題点}

上記の技術協力活動の具体的な問題点については， 大別して三つの分野にその焦点を絞りこむことがで きる. 先ず第一はカリキュラムの改正に伴う問題で ある. 教育制度をIMOの「STCW条約，1978टそ の改正に伴う規約」に叶うものとするためには, カ リキュラム・シラバス・レッスンプランといった一 連の策定の見直しが必要となり，これに伴う教育施 設・機材・教材の新たな導入が必要となる. 目下の 


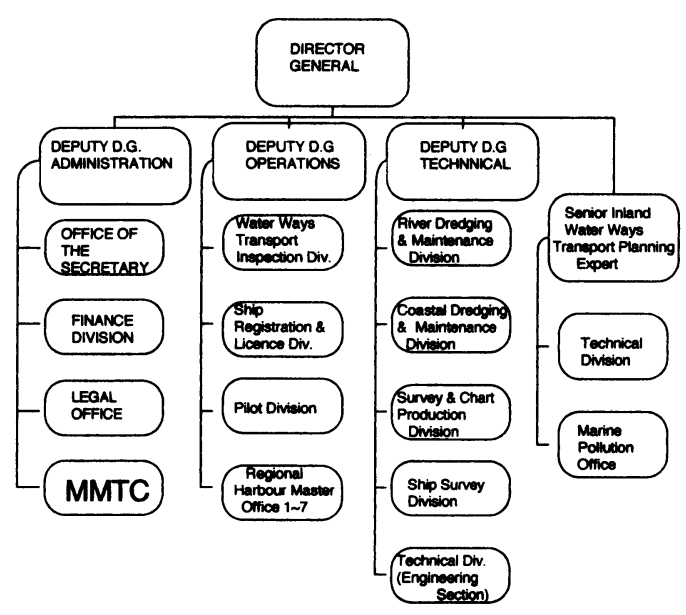

〈Fig. 4 >Organization Chart of Harbour Department

ところMMTCは，この部門での技術援助をデン マーク政府（実際の実施機関はDANIDAの名で 知られるDanish International Development Agency）に求めており, 本年10月末でようやくそ の原案が出来上がった次第である. 従って, 我々と してもこのプランに頼らざるを得ず, 常に彼らの作 業を念頭に置きつつ，あらゆる資材・教材（例えば， 工場実習機材の選定之購入に絡む問題や教科書選定 の際の購入と運用に絡む問題）の手配を行わねばな らない（実際には, カウンターパートとレッスンプ ランの方案を検討しつつ, 具体的な奏施方案を作成 することになる）.

また第二の問題は，実際のカウンターパートの人 材の不足である. R/Dに謳われている各科 5 名の カウンターパートは実質ではその数を満たしておら ず, 現状のままでは新たに導入した機材の充分な活 用並びに適当な維持管理は期待できない，人材の不 足は，根本的にはMMTCそのものが運輸通信省内 の港湾局の一機構であることにあろう（Organization Chart of Harbour Department〈Fig. 4〉 参照）。その内部で人事異動が, $2 \sim 3$ 年に一回行 われているのが現状である. 従って, その設立当初 から教官の殆どが海軍等の外部からの講師に頼って いるのが実情であり，この辺りは夕イ国独特の軍・ 民活用方策のようにも思われるが，このカリキュラ ム等の改革を機に, 今後はパーマネントの講師即ち プロジェクト・カウンターパートを積極的に採用す る必要があるものと考えられる. しかし, 現状にお
けるMMTCの所在地の不便さ（交通渋滞の影響も 大きい), 民間に比べた場合の技術職員の給与の低さ 等がその妨げになっているようである. これらを克 服するためには，MMTC自体の省内における位置 付けを, なんらかの方法で高めていくか, 或は一つ の独立した教育機関として, 新たに人員配置の見直 しを行う等の施策も必要なのではないかと思われる.

第三は，海運関連機関の官・民の連携の不十分さ であろうと思われる. 例を挙げると, MMTC卒業 生の就職調査を行おうとしても，その資料となる データがない，また海運界からMMTCに対する求 人活動が, 我が国では考えられないくらい不活発で ある. 従ってJICAが現在徹底させようとしている 「PCMによるプロジェクト管理」の最終段で重要 な, エヴァリュエーションの際の具体的な評価項目 として, 極めて抽象的な項目しか挙げられないので ある.

\section{6. おわりに}

平成 5 年 3 月の $\mathrm{R} / \mathrm{D}$ 調印にはじまり, 約 1 年半 を経過した本プロジェクトについての現状を, 一専 門家の立場から書かせて頂きましたが，今一番大切 に思うことは，カウンターパート自身から「専門家 と一緒に働いて, 何か今後の参考となるものを得ら れた!」と思われるような技術協力にしたいという ことです. 勿論プロジェクト自体が成功裡に終わる ことを望みますが，それは相手国と我が国の諸条件 が極めてうまく調和した時に, 初めて実現の可能性 があるように思われますので，個人の目標としては 漠然としか考えていない状態です。今後はJICAの 研修のときに聞いた「3つのあ（あせらず・あなど らず・あきらめず）」を心がけて, 残りの任期を勤 めようと思っています。

\section{参考文献}

1） JICA専門家養成研修資料「任国情報」タイ（1991年 版)

2) JICA専門家養成研修資料「プロジェクト方式技術協 力の手引」（平成 4 年 4 月版）

3) JICA調查団資料「タイ王国船員教育訓練センター拡 張近代化プロジェクト（実施協議調查団報告書）」 (平成 5 年 3 月版) 
4 )「Seafarer Situation in Thailand」 (Harbour Department, Ministry of Transport \& Communications, published in February 1993)

5 ）「タイ王国船員教育訓練センター広報パンフレット」 (1994年度版)

6 ) ベーシック・世界の紛争地図（日本経済新聞社）

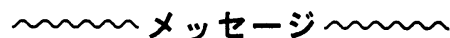

筆者は本プロジェクトに着任するまで，1度もタイに来た ことがありませんでした．従って初めてタイの文化に接した 時は，その現実主義の力強さに圧倒されそうになりました。 着任以来 1 年が過ぎ，ようやく道を歩く時に眺める看板の字 が読めたり，道端のストリート・ベンダーの言葉の断片が 判ったりするようになって始めて，この国の現実志向の根元 が見え始めてきたように感じられます，それと同時に，自身 の浅学非才を痛感する次第です. 今後の読者諸兄の温かい御 指導・御荗谜を期待して止みません. 